\title{
Child Rights As Perceived by the Community Members in India
}

\author{
Sibnath Deb ${ }^{1}$, Jiandong $\mathrm{Sun}^{2}$, Anjali Gireesan ${ }^{3}$, Aneesh $\mathrm{Kumar}^{4} \&$ Anindita Majumdar ${ }^{5}$ \\ ${ }^{1}$ Department of Applied Psychology, Pondicherry University, Puducherry, India \\ ${ }^{2}$ School of Public Health \& Social Work, Faculty of Health, Queensland University of Technology, Brisbane, \\ Australia \\ ${ }^{3}$ Department of Psychology, Mithibai College of arts, Chauhan Institute of Science and Amrutben and Jivanlal \\ college of Commerce, Mumbai, India \\ ${ }^{4}$ Department of Psychology, Christ University, Bangalore, India \\ ${ }^{5}$ Department of Applied Psychology, University of Calcutta, Kolkata, India \\ Correspondence: Sibnath Deb, Department of Applied Psychology, Pondicherry University (A Central \\ University), R.V.Nager, Kalapet, Puducherry -605 014, India. E-mail: sibnath23@gmail.com
}

\author{
Received: September 1, 2015 Accepted: October 21, 2015 Online Published: December 25, 2015 \\ doi:10.5539/ilr.v5n1p1 \\ URL: http://dx.doi.org/10.5539/ilr.v5n1p1
}

Funding: The project was supported by the Indian Council of Social Science Research (ICSSR), Ministry of Human Resource Development, Government of India. Grant Ref. No.02/342/2011/RP, dated 28.03.2012.

\begin{abstract}
Attitudes, knowledge, and perceptions of an individual influence their behavior as well as culture of a society. The objective of the study was to understand the attitudes and knowledge of 584 Indian community members regarding child rights and their perceptions about whether selected child rights were secured in reality. Overall attitudes of vast majority (96-98\%) of the participants towards child rights were found to be positive i.e., children should have rights in various respects except issue like right to meet others (Article 15 of CRC). Knowledge of majority of the participants about child rights related legislations was moderate and varied across the cities while participants were unanimous about poor lived experiences of child rights in reality. So far as attitude and perception are concerned about child rights, there was a significant difference in the distribution between cities $(\mathrm{p}<0.01)$. Overall, the Rights of Children to Free and Compulsory Education Act, 2009 had the highest awareness $(91.3 \%, n=533)$, followed by the Child Labour (Prohibition and Regulation) Act, 1986 $(89.7 \%, n=523)$ and the Prohibition of Child Marriage Act, 2006 (89.6\%, $n=523)$. Findings of the present study speak in favor of community awareness about child rights and penalties for violation of child rights.
\end{abstract}

Keywords: child rights, attitude, knowledge, perception, parents, teachers, legislations

\section{Introduction}

Parents' especially the mother is the first social agent to a child, followed by teachers as an individual during his/her childhood spends maximum time in the educational institution. Therefore, knowledge and perception of parents and teachers about quality parenting, quality care and child rights are very important as these knowledge and perceptions mostly determine their behaviour and attitude towards children and students. Evidence indicates that a greater extensive research was done on prevalence of various forms of violence against children and its consequences on mental health, career growth and social life in the western countries (Kempe et al., 1962; Gilbert et al., 2009; Ronan et al., 2009; May-Chahal \& Cawson, 2005; Finkelhor et al., 2010) compared to Asian countries including India (Yeatman et al., 1976; Bhattacharyya, 1979; Mehta et al., 1979; de Silva, 1981; Segal, 1992, 1995).

Culture plays an important role in forming parental attitudes about how children should be disciplined (Runyan et al., 2010). Education to enhance knowledge and interpersonal skills has shown to be effective in improving gender attitudes in young Indian men (Verma et al., 2006). Adults' attitudes towards children's place in society and their rights are inextricably related with a society's culture, including how it perceives and treats children. In this regard, the attitudes and knowledge of all adults are important, but some sectors of the adult population are particularly influential. 
In the context of child maltreatment prevention in India, Segal (1992) has asserted that it is vital to ascertain the perceptions of those with greatest capacity to intervene. It would be premature to develop intervention programs if key individuals do not identify selected acts as abusive or violent. Similarly, it may be particularly important to understand the nature of Indian parents' and teachers' attitudes and knowledge towards children's rights, so that insights can be gained into the general cultural understanding and perceptions towards children. In turn, this evidence can illuminate aspects of the culture which may be able to enhance, and can inform about both the nature of effective strategies to better secure particular children's rights, such as the right to education, and effective prevention programs against child maltreatment.

It is relevant to mention here that the findings of various studies especially regarding prevalence and consequences of child abuse and neglect made global policy makers to think of welfare and protection of children worldwide, which resulted in formulation of global policy for child rights 'The United Nations Convention on the Rights of the Child (UNCRC)' in 1990. It was a landmark development towards recognition of serious sufferings and maltreatment of children worldwide. The UNCRC clearly defined the specific rights that children should enjoy across the nations and society. The UNCRC was ratified by nearly every nation. Before the 1990s, many nations had introduced legislation and policies promoting children's rights, but the UNCRC heightened sensitivity to the need for domestic legislation, policy and practices to promote children's rights generally, including protection from maltreatment. India, for example, which acceded to the UNCRC on 11 December 1992, has enacted numerous statutes promoting children's rights since the early 1990s, while having earlier enacted legislation about specific elements of children's welfare.

Like all international legislations, the Government of India came out with a number of legislations from time to time as the situation demanded. Legislation promoting children's civil and social rights is most notably embodied in the Constitution of India (1949). Article 14 guarantees equality before the law and article 15 prohibits discrimination based on gender, caste, race and religion. Article 21A directs all States to provide free and compulsory education to all children between the ages of 6 to 14 years. Article 24 prohibits children under 14 from being employed in factories and mines, and from working in any hazardous employment. Article 23 prohibits the trafficking of human beings and forced labour. Freedom of religion is conferred by article 25 . Article 39 directs policy to ensure that children are protected from inappropriate work, and from all forms of exploitation. Other federal statutes also contain provisions promoting children's rights and welfare.

The Juvenile Justice (Care and Protection of Children) Act, 2000 makes it an offence to procure a child for employment (section 26), and to use a child for begging (section 24). The Child Labour (Prohibition and Regulation) Act, 1986 prohibits the employment of children under 15 in certain occupations. The Child Marriage Restraint Act, 1929 prohibits males under 21 and females under 18 from marrying. Further, The Prohibition of Child Marriage Act, 2006 prohibits a male adult above eighteen years from contracting a child marriage. Numerous other statutes promote commitments to child health (the Infant Milk Substitutes, Feeding Bottles and Infant Foods (Regulation of Production, Supply and Distribution) Act, 1992) 7 and the elimination of discrimination (Persons with Disabilities (Equal Opportunities, Protection of Rights, and Full Participation) Act, 1995).

The legislation aimed at reducing and responding to various manifestations of child maltreatment includes the Indian Penal Code, 1860, which contains provisions regarding the prosecution of offences, which apply where the victim is a child. The Juvenile Justice (Care and Protection of Children) Act, 2000 establishes certain offences including cruelty against a juvenile. Several statutes including the Immoral Traffic (Prevention) Act, 1956 and the Juvenile Justice Act address child trafficking, which is a significant problem in India (Sen 2005 ; Ghosh 2009; Deb et al., 2011). As well, there are general national laws and policy frameworks which profess a commitment to children's rights and welfare. The National Charter for Children, 2003, Article 9 states that all children have the right to be protected against neglect, maltreatment, injury, trafficking, sexual and physical abuse of all kinds, corporal punishment, torture, violence, and degrading treatment. The National Policy for Children, 1974 expresses the national government's commitment to providing adequate services to children, both before and after birth, to ensure their full physical, mental, and social development. The Commissions for Protection of Child Rights Act, 2005 provides for a National Commission and State Commissions for the Protection of Child Rights and Children's Courts, aiming to provide speedy trials in cases of offences against children or violations of child rights. Aiming to address the particularly heinous custom of sex-selective abortion (and abandonment) caused by the distinct societal preference across social, religious and economic strata for male births, the Pre-natal Diagnostic Techniques (Regulation and Prevention of Misuse) Act, 1994 prohibits the determination and disclosure of the sex of foetuses.

Literacy rate among Indian children is very low. Only one out of two children in India gets the opportunity for 
primary education. The Right of Children to Free and Compulsory Education Act or the Right to Education Act (RTE) is an Indian legislation enacted by the Parliament of India on 4 August 2009 which was a right step for ensuring education for all children although taken after 60 years of Indian Independence. Given the increasing rate of sexual offences against children across the country in the last decade and to combat this problem, The Protection of Children from Sexual Offences Act, 2012 (POCSO Act, 2012) was passed by the Indian Parliament which mandated reporting of offences against children without specifying the category of person or profession except media profession.

Apart from the domestic laws, India has also expressed a commitment to children's rights through its accession to the UNCRC, the core international legal instrument in this context. Among a range of fundamental rights, States parties are committed to the promotion and implementation of children's rights to: education (article 28); health and medical care (article 24); freedom of expression (which includes the right to obtain information) (article 13); freedom of association (article 15); rest, leisure, play, and participation in cultural and artistic activities (article 31); protection from economic exploitation and work that threatens his/her health, education and development (article 32); and the right of children from minority communities and indigenous populations to enjoy their own culture and to practice their own religion and language (article 30). The UNCRC also obliges States parties to take all appropriate legislative, administrative, social and educational measures to protect children from all forms of abuse and exploitation (article 19). It is imperative to understand the attitudes and knowledge of parents and teachers about children's fundamental rights. The lack of evidence in this field impedes both the development of a positive culture regarding children, and effective programs promoting child welfare and preventing child maltreatment.

It seems reasonable to postulate that greater knowledge of children's rights in legal instruments, together with more positive attitudes towards those rights and to children's welfare generally, is conducive to the generation of a more positive societal culture for children. This in turn is more likely to promote children's rights in lived experience (such as the right to education), and to produce a reduction in abusive behaviour. As well, finding evidence about the state of parents' and teachers' attitudes and knowledge in these domains can illuminate whether there is any need for further awareness-raising, and can perhaps even inform effective interventions.

Very few researchers have explored the attitudes, knowledge and perceptions of parents and teachers about children's legal rights. Some work has been done in South Asia and surrounding regions (Ben-Arieh et al., 2006 ; Chen et al., 2007 ; Hannum et al., 2009), and studies elsewhere are more frequent, but are still relatively rare (Casas et al., 2006; Day et al., 2006 ; Bunting et al., 2010). Exploring the attitudes and knowledge of parents and teachers about children's rights is important for many reasons as indicated by the previous study (Deb \& Mathews 2012). A number of previous studies clearly indicated that parents and teachers are the perpetrators for physical and psychological abuse of a large number of children worldwide (Deb \& Modak 2010; Deb \& Walsh 2011). One and perhaps the only Indian study carried out in Agartala, Tripura - a North Eastern States in India on knowledge and perception of parents and teachers about child rights highlighted that most parents and teachers had positive attitudes about children's rights, including rights to health and education, and freedom from child marriage and inappropriate work. Yet, about one quarter of participants did not think children should have the rights to freedom of expression and association. Knowledge of laws promoting children's rights was poor. Most parents and teachers perceived a denial of seven key rights in Indian children's lived experience. Overall, findings suggest a need to heighten awareness of children's rights and needs, which can improve attitudes towards the treatment of children (Deb \& Mathews 2012). The findings of the same study indicates the knowledge gap among the parents and teachers about child rights and their attitude towards child rights concerning freedom of expression and association are issues of concern for the policy makers and child right activists. Therefore, the researchers became interested from the findings of the same study to see how parents, teachers, and community members of other cities of India look at the issue.

\section{Objective of the Study}

The objective of the presents study was to understand the knowledge, attitude and perception of parents, teachers and community members of five cities in India about child rights and child rights related legislations. Finally, the findings of the empirical study will help to draw some conclusions about future strategies to enhance children's rights in India. 


\section{Methods}

\subsection{Design}

A multi-centric cross-sectional study was carried out to achieve the objective of the study by using a specially designed structured questionnaire.

\subsection{Coverage}

The study was conducted covering five cities in India viz., Puducherry, Kerala, Chennai, Delhi and Kolkata. A brief description of the study sites is as follows:

(i) Delhi is the capital of India and is also known as the National Capital region (NCR).It is one of the seven Union territories of India. It is the second most populated metro city of the Indian sub-continent situated in the Northern parts of the country. Inhabited by people from variety of cultures from across the country, its population accounts to approximately 16 million out of which 8.9 million is constituted by males and 7.8 million is constituted by females. The literacy rate of this state is $86.21 \%$ with male literacy rate being $90.94 \%$ and female literacy rate being $68.85 \%$. The child population (0-6 years) of the state comes about to $11.97 \%$ (Census 2011).The IRMB Report (2009) has shown that the dropout rate of the state is $5.00 \%$ which is greater than the national average of $4.28 \%$.

(ii) Kolkata is the capital city of West Bengal and is also one of the metro cities of the Indian sub-continent situated towards the eastern parts. Its population is approximately 4.48 million of which nearly 2.36 million are males and 2.12 million are females. The literacy rate of this state is $87.14 \%$ with male literacy rate being $89.08 \%$ and female literacy rate being $84.98 \%$. The child population (0-6 years) of the state comes about to 6.69\% (Census 2011).The IRMB report (2009) has shown that the dropout rate of the state is $5.23 \%$ which is greater than the national average of $4.28 \%$.

(iii) Chennai is the capital city of the state of Tamil Nadu and is yet another metro city of the Indian sub-continent situated towards the southern parts of the country. Its population is approximately 8.69 million of which nearly 4.38 million are males and 4.30 million are females. The literacy rate of this state is $90.35 \%$ with male literacy rate being $93.57 \%$ and female literacy rate being $84.98 \%$. The child population (0-6 years) of the state comes about to $9.39 \%$ (Census of India, 2011).The IRMB Report (2009) has shown that the dropout rate of the state is $0.63 \%$ which is less than the national average.

(iv) Kerala is a small state along the Western Ghats and situated towards the Southern parts of the Indian-Subcontinent. It has been often referred to as "God's own country "because" of its scenic and natural spread of flora and fauna. Its population is approximately 33.38 million and here the classification is basically spelled in terms of rural and urban population. In the census 2011, Kerala has topped as the state having the best Sex-ratio as well as literacy rate. The literacy rate of this state is $93.91 \%$ with rural literacy rate being $92.92 \%$ and urban literacy rate being $94.99 \%$. The child population (0-6 years) of the state comes about to $10.01 \%$ in rural regions and $9.88 \%$ in urban regions (Census of India, 2011).The IRMB Report (2009) has shown that the dropout rate of the state is $0.37 \%$ which is less than the national average and has achieved the milestone of having the lowest dropout rate among all the Indian states.

(v) Pondicherry is one of the seven Union territories situated in the southern parts of the Indian sub-continent. Its population is approximately 9.50 million of which nearly 4.68 million are males and 4.82 million are females. The literacy rate of this state is $85.44 \%$ with male literacy rate being $91.23 \%$ and female literacy rate being $79.86 \%$. The child population (0-6 years) of the state comes about to $10.51 \%$ (Census 2011). The IRMB report (2009) has shown that the dropout rate of the state is $0.55 \%$ which is less than the national average.

\subsection{Subject}

The study covered three categories of subjects like parents, teachers and community members from all the five cities in India following convenience sampling technique method.

\subsection{Study Tool}

The Questionnaire for Parents/Teachers (QPT), a semi-structured instrument, was developed by Sibnath Deb (Deb 2007) to gather information about the attitudes, knowledge and perceptions of parents and teachers 
regarding children's rights. The QPT has three sections.

- Section 1 gathered demographic and socioeconomic information.

- Section 2 contained items gathering information about attitudes towards children's rights. This section has eight items exploring attitudes towards certain rights, and it also explored perceptions about the lived experience of children regarding certain rights.

- Section 3 contained six items exploring participants' knowledge of Indian laws regarding children's rights and protection from maltreatment.

The draft QPT was checked by three experts for clarity, accuracy and content validity. Informed by feedback, changes were made and it was then piloted with 30 subjects ( 15 parents and 15 teachers) to further assess these features. Informed by pilot study findings, final modifications were made and this final version of the QPT was used in the main study. Data were collected from participants from October to December 2012 by self-administration of the QPT. Participants were assured of confidentiality and anonymity and data was stored in a secure location.

\subsection{Data Collection and Analysis}

The data were collected from parents, teachers and community members across the five cities of Delhi (Parents -50, Teachers-76, Community members-50), Chennai (Parents -51, Teachers-32, Community members-9), Kolkata (Parents -42, Teachers-27, Community members-42), Puducherry (Parents -43, Teachers-45, Community members-16) and Kerala (Parents -55, Teachers- 28, Community members-18). Thus a total of 241 parents, 209 teachers and 135 community members constituted the sample.

The collected data were edited, entered in computer, and aggregated to generate descriptive statistics. Aggregate scores for attitudes, knowledge and perception were done first. Thereafter, Chi-square test was used for analytical comparison between the groups. Non-parametric tests were used because these scores were not normally distributed. This apart, multiple regression analysis for knowledge and perception about child rights was done.

\section{Results}

\subsection{Sample Description}

For all demographic variables, the distribution was significantly different between the five Indian cities. 
Table 1. Description of the sample by city $(\mathrm{N}=584)$

\begin{tabular}{|c|c|c|c|c|c|}
\hline \multirow[t]{2}{*}{ Variables } & Puducherry & Kerala & Chennai & Delhi & Kolkata \\
\hline & $\mathrm{n}=104$ & $\mathrm{n}=101$ & $\mathrm{n}=92$ & $\mathrm{n}=176$ & $\mathrm{n}=111$ \\
\hline \multicolumn{6}{|l|}{ Category } \\
\hline Parents & $43(41.4)$ & $55(54.5)$ & $51(55.4)$ & $50(28.4)$ & $42(37.8)$ \\
\hline Teachers & $45(43.3)$ & $28(27.7)$ & $32(34.8)$ & $76(43.2)$ & $27(24.3)$ \\
\hline $\mathrm{CMs}$ & $16(15.4)$ & $18(17.8)$ & $9(9.8)$ & $50(28.4)$ & $42(37.8)$ \\
\hline \multicolumn{6}{|l|}{ Gender } \\
\hline Males & $31(29.8)$ & $51(50.5)$ & $23(25.0)$ & $80(45.5)$ & $38(34.2)$ \\
\hline Females & $73(70.2)$ & $50(49.5)$ & $69(75.0)$ & $96(54.6)$ & $73(65.8)$ \\
\hline \multicolumn{6}{|l|}{ Age } \\
\hline$<30$ years & $29(27.9)$ & $48(47.5)$ & $7(7.6)$ & $43(24.4)$ & $19(17.1)$ \\
\hline $31-35$ & $51(49.0)$ & $19(18.8)$ & $14(15.2)$ & $30(17.1)$ & $21(18.9)$ \\
\hline $36-40$ & $19(18.3)$ & $14(13.9)$ & $17(18.5)$ & $48(27.3)$ & $12(10.8)$ \\
\hline $41-45$ & $4(3.9)$ & $9(8.9)$ & $15(16.3)$ & $43(24.4)$ & $14(12.6)$ \\
\hline $46-50$ & $1(1.0)$ & $5(5.0)$ & $15(16.3)$ & $10(5.7)$ & $20(18.0)$ \\
\hline$\geq 51$ years & $0(0.0)$ & $6(5.9)$ & $24(26.1)$ & $2(1.1)$ & $25(22.5)$ \\
\hline \multicolumn{6}{|l|}{ Education level } \\
\hline Below graduate & $33(31.7)$ & $15(14.9)$ & $8(8.7)$ & $0(0.0)$ & $6(5.4)$ \\
\hline Graduate & $41(39.4)$ & $20(19.8)$ & $34(37.0)$ & $42(23.9)$ & $30(27.0)$ \\
\hline Postgraduate & $30(28.9)$ & $66(65.4)$ & $50(54.4)$ & $134(76.1)$ & $75(67.6)$ \\
\hline \multicolumn{6}{|l|}{ Number of children } \\
\hline None & $56(53.9)$ & $23(22.8)$ & $13(14.1)$ & $62(35.2)$ & $19(17.1)$ \\
\hline One & $13(12.5)$ & $30(29.7)$ & $19(20.7)$ & $81(46.0)$ & $33(29.7)$ \\
\hline Two or more & $35(33.7)$ & $48(47.5)$ & $60(65.2)$ & $33(18.8)$ & $59(53.2)$ \\
\hline \multicolumn{6}{|l|}{ Income level } \\
\hline Low $(<$ Rs.20K) & $42(40.4)$ & $51(53.7)$ & $20(21.7)$ & $4(2.3)$ & $6(5.5)$ \\
\hline Middle(20 - 50K) & $53(51.0)$ & $36(37.9)$ & $39(42.4)$ & $68(39.5)$ & $35(31.8)$ \\
\hline $\operatorname{High}(50 \mathrm{~K}+)$ & $9(8.7)$ & $8(8.4)$ & $33(35.9)$ & $100(58.1)$ & $69(62.7)$ \\
\hline
\end{tabular}

Note. $\mathrm{CMs}=$ community members; Rs=Indian Rupees; $\mathrm{K}=$ thousand

The distribution of all variables was significantly different across cities (Chi-square test $\mathrm{p}<0.001$ )

\subsection{Attitudes towards Child Rights}

Overall, for all items listed in Table 2 except the second ("Do you think a child should have the right to meet others, irrespective of background?"), the vast majority (96-98\%) reported positive attitudes, considering children should have rights in various respects. However, for the right to meet others, irrespective of background, about one quarter $(25.6 \%, \mathrm{n}=148)$ responded negatively.

For all selected rights, there was a significant difference in the distribution between cities (Table 2, $\mathrm{p}<0.01$ ). 
Table 2. Prevalence of positive attitudes towards child rights in five Indian cities $(\mathrm{N}=584)$

\begin{tabular}{|c|c|c|c|c|c|}
\hline \multirow{2}{*}{ Items } & Puducherry & Kerala & Chennai & Delhi & Kolkata \\
\hline & $\mathrm{n}=104$ & $\mathrm{n}=101$ & $\mathrm{n}=92$ & $\mathrm{n}=176$ & $\mathrm{n}=111$ \\
\hline $\begin{array}{l}\text { Do you think a child should have the right to } \\
\text { express his/her views, obtain information, and } \\
\text { make ideas or information known? }\end{array}$ & $102(98.1)$ & $\begin{array}{l}93 \\
(93.9)\end{array}$ & $\begin{array}{l}82 \\
(92.1)\end{array}$ & $\begin{array}{l}176 \\
(100.0)\end{array}$ & $\begin{array}{l}110 \\
(99.1)\end{array}$ \\
\hline $\begin{array}{l}\text { Do you think a child should have the right to meet } \\
\text { others, irrespective of background? }\end{array}$ & $36(34.6)$ & $\begin{array}{l}72 \\
(72.7)\end{array}$ & $\begin{array}{l}72 \\
(80.9)\end{array}$ & $\begin{array}{l}157 \\
(89.2)\end{array}$ & $94(84.7)$ \\
\hline $\begin{array}{l}\text { Do you think a child should have the right to an } \\
\text { adequate of basic standard of health care? }\end{array}$ & 97 (93.3) & $\begin{array}{l}98 \\
(99.0)\end{array}$ & $\begin{array}{l}85 \\
(96.6)\end{array}$ & $\begin{array}{l}176 \\
(100.0)\end{array}$ & $\begin{array}{l}110 \\
(99.1)\end{array}$ \\
\hline $\begin{array}{l}\text { Do you think a child has the right to an education } \\
\text { including the right to free education at primary } \\
\text { school level? }\end{array}$ & $103(99.0)$ & $\begin{array}{l}96 \\
(97.0)\end{array}$ & $\begin{array}{l}83 \\
(93.3)\end{array}$ & $\begin{array}{l}176 \\
(100.0)\end{array}$ & $\begin{array}{l}110 \\
(99.1)\end{array}$ \\
\hline $\begin{array}{l}\text { Do you think children from minority communities } \\
\text { and indigenous populations have the right to enjoy } \\
\text { their own culture and to practice their own } \\
\text { religion and language? }\end{array}$ & $100(96.2)$ & $\begin{array}{l}91 \\
(91.9)\end{array}$ & $\begin{array}{l}82 \\
(92.1)\end{array}$ & $\begin{array}{l}176 \\
(100.0)\end{array}$ & $\begin{array}{l}105 \\
(94.6)\end{array}$ \\
\hline $\begin{array}{l}\text { Do you think a child should have the right to } \\
\text { leisure, play and participation in cultural and } \\
\text { artistic activities? }\end{array}$ & $96(92.3)$ & $\begin{array}{l}94 \\
(95.0)\end{array}$ & $\begin{array}{l}86 \\
(96.6)\end{array}$ & $\begin{array}{l}176 \\
(100.0)\end{array}$ & $\begin{array}{l}111 \\
(100.0)\end{array}$ \\
\hline $\begin{array}{l}\text { Do you think a child has the right to be protected } \\
\text { from work that threatens his/her health, education } \\
\text { and development? }\end{array}$ & $103(99.0)$ & $\begin{array}{l}95 \\
(96.0)\end{array}$ & $\begin{array}{l}83 \\
(93.3)\end{array}$ & $\begin{array}{l}176 \\
(100.0)\end{array}$ & $\begin{array}{l}111 \\
(100.0)\end{array}$ \\
\hline
\end{tabular}

\subsection{Knowledge about Child Rights}

The awareness of child right related laws and regulations varied greatly among the cities. Overall, the Rights of Children to Free and Compulsory Education Act 2009 had the highest awareness (91.3\%, n=533), followed by the Child Labour (Prohibition and Regulation) Act, 1986 (89.7\%, n=523) and the Prohibition of Child Marriage Act, 2006 (89.6\%, n=523). The Infant Milk Substitutes, Feeding Bottles and Infant Foods (Regulation of Production, Supply and Distribution) Act, 1992 had the lowest awareness in this sample, with only 38.0\% $(n=221)$ reporting awareness of this act.

For all items except the awareness of "Infant Milk Substitutes, Feeding Bottles and Infant Foods (Regulation of Production, Supply and Distribution) Act, 1992", there was a significant difference in the distribution between cities (Table 3, $\mathrm{p}<0.05$ ). 
Table 3. Prevalence of awareness of child right regulations in five Indian cities ( $\mathrm{N}=584)$

\begin{tabular}{lllllll}
\hline \multirow{2}{*}{ Items } & Puducherry & Kerala & Chennai & Delhi & Kolkata \\
\cline { 2 - 6 } & & $\mathrm{n}=104$ & $\mathrm{n}=101$ & $\mathrm{n}=92$ & $\mathrm{n}=176$ & $\mathrm{n}=111$ \\
\hline Are you aware of provisions in the Indian & \multirow{2}{*}{$75(72.1)$} & 66 & 59 & 23 & 77 \\
Constitution protecting child rights? & & $(65.4)$ & $(64.8)$ & $(13.1)$ & $(69.4)$ \\
Are you aware of other laws which protect & & 64 & 45 & 173 & 53 \\
children's rights in India? & $65(62.5)$ & $(63.4)$ & $(48.9)$ & $(98.3)$ & $(47.8)$ \\
Have you heard of the UN Convention on the & & 47 & 33 & 77 & 62 \\
Rights of the Child? & $59(56.7)$ & $(46.5)$ & $(35.9)$ & $(43.8)$ & $(55.9)$ \\
\hline
\end{tabular}

Knowledge about specific Indian laws about children's rights and welfare

Are you aware of:

\begin{tabular}{|c|c|c|c|c|c|}
\hline $\begin{array}{l}\text { The Rights of Children to Free and Compulsory } \\
\text { Education Act 2009? }\end{array}$ & $94(90.4)$ & $\begin{array}{l}92 \\
(91.1)\end{array}$ & $\begin{array}{l}78 \\
(84.8)\end{array}$ & $\begin{array}{l}173 \\
(98.3)\end{array}$ & $\begin{array}{l}96 \\
(86.5)\end{array}$ \\
\hline $\begin{array}{l}\text { The Commissions for Protection of Child Rights } \\
\text { Act, 2005? }\end{array}$ & $59(56.7)$ & $\begin{array}{l}71 \\
(72.5)\end{array}$ & $\begin{array}{l}54 \\
(58.7)\end{array}$ & $\begin{array}{l}61 \\
(34.7)\end{array}$ & $\begin{array}{l}65 \\
(58.6)\end{array}$ \\
\hline $\begin{array}{l}\text { The Juvenile Justice (Care and Protection of } \\
\text { Children) Act, 2000? }\end{array}$ & $87(83.7)$ & $\begin{array}{l}67 \\
(66.3)\end{array}$ & $\begin{array}{l}37 \\
(40.2)\end{array}$ & $\begin{array}{l}63 \\
(35.8)\end{array}$ & $\begin{array}{l}65 \\
(58.6)\end{array}$ \\
\hline $\begin{array}{l}\text { The Child Labour (Prohibition and Regulation) } \\
\text { Act, 1986? }\end{array}$ & $92(88.5)$ & $\begin{array}{l}90 \\
(90.0)\end{array}$ & $\begin{array}{l}77 \\
(83.7)\end{array}$ & $\begin{array}{l}176 \\
(100.0)\end{array}$ & $\begin{array}{l}88 \\
(79.3)\end{array}$ \\
\hline The Indian Penal Code, $1860 ?$ & $96(92.3)$ & $\begin{array}{l}47 \\
(47.0)\end{array}$ & $\begin{array}{l}42 \\
(45.7)\end{array}$ & $\begin{array}{l}76 \\
(43.2)\end{array}$ & $\begin{array}{l}43 \\
(38.7)\end{array}$ \\
\hline $\begin{array}{l}\text { The Prohibition of Child Marriage Act, } 2006 \text { (Jan } \\
10,2007) ?\end{array}$ & $89(85.6)$ & $\begin{array}{l}86 \\
(85.2)\end{array}$ & $\begin{array}{l}78 \\
(84.8)\end{array}$ & $\begin{array}{l}175 \\
(99.4)\end{array}$ & $\begin{array}{l}95 \\
(85.6)\end{array}$ \\
\hline The Child Marriage Restraint Act, $1929 ?$ & $92(88.5)$ & $\begin{array}{l}74 \\
(74.0)\end{array}$ & $\begin{array}{l}49 \\
(53.3)\end{array}$ & $17(9.7)$ & $\begin{array}{l}63 \\
(56.8)\end{array}$ \\
\hline Immoral Traffic (Prevention) Act, $1956 ?$ & $69(66.4)$ & $\begin{array}{l}65 \\
(65.7)\end{array}$ & $\begin{array}{l}38 \\
(41.3)\end{array}$ & $\begin{array}{l}37 \\
(21.0)\end{array}$ & $\begin{array}{l}61 \\
(55.0)\end{array}$ \\
\hline $\begin{array}{l}\text { Infant Milk Substitutes, Feeding Bottles and } \\
\text { Infant Foods (Regulation of Production, Supply } \\
\text { and Distribution) Act, 1992? }\end{array}$ & $45(43.3)$ & $\begin{array}{l}38 \\
(38.4)\end{array}$ & $\begin{array}{l}39 \\
(42.4)\end{array}$ & $\begin{array}{l}53 \\
(30.1)\end{array}$ & $\begin{array}{l}46 \\
(41.4)\end{array}$ \\
\hline $\begin{array}{l}\text { Persons with Disabilities (Equal Opportunities, } \\
\text { Protection of Rights and Full Participation) Act, } \\
\text { 1995? }\end{array}$ & $74(71.8)$ & $\begin{array}{l}70 \\
(70.7)\end{array}$ & $\begin{array}{l}59 \\
(64.1)\end{array}$ & $\begin{array}{l}60 \\
(34.1)\end{array}$ & $\begin{array}{l}79 \\
(71.2)\end{array}$ \\
\hline $\begin{array}{l}\text { Pre-Conception and Pre-natal Diagnostic } \\
\text { Technique (Prohibition of Sex Selection) Act, } \\
\text { 1994? }\end{array}$ & $99(95.2)$ & $\begin{array}{l}72 \\
(72.7)\end{array}$ & $\begin{array}{l}53 \\
(57.6)\end{array}$ & $\begin{array}{l}28 \\
(15.9)\end{array}$ & $\begin{array}{l}89 \\
(80.2)\end{array}$ \\
\hline
\end{tabular}

\subsection{Perception about Current Status of Child Rights}

The proportion of positive perception was relatively low, ranging from $24.4 \%$ (Do you think children are protected from work that threatens their health, education and development?) to $48.9 \%$ (Do you think children enjoy the right to express their views, obtain information, and make ideas or information known?) in the overall sample.

For all items, there was a significant difference in the distribution between cities $(\mathrm{p}<0.05)$. 
Table 4. Prevalence of positive perception (Number of "Yes" responses) about child right regulations in five Indian cities $(\mathrm{N}=584)$

\begin{tabular}{|c|c|c|c|c|c|}
\hline \multirow{2}{*}{ Items } & Puducherry & Kerala & Chennai & Delhi & Kolkata \\
\hline & $\mathrm{n}=104$ & $\mathrm{n}=101$ & $\mathrm{n}=92$ & $\mathrm{n}=176$ & $\mathrm{n}=111$ \\
\hline $\begin{array}{l}\text { Do you think children enjoy the right to express their } \\
\text { views, obtain information, and make ideas or } \\
\text { information known? }\end{array}$ & $40(38.5)$ & $\begin{array}{l}53 \\
(52.5)\end{array}$ & $\begin{array}{l}58 \\
(63.7)\end{array}$ & $\begin{array}{l}65 \\
(36.9)\end{array}$ & $\begin{array}{l}69 \\
(62.2)\end{array}$ \\
\hline $\begin{array}{l}\text { Do you think children are allowed to meet others } \\
\text { irrespective of background, and to join or form } \\
\text { associations? }\end{array}$ & $39(37.5)$ & $\begin{array}{l}32 \\
(32.0)\end{array}$ & $\begin{array}{l}43 \\
(47.3)\end{array}$ & $\begin{array}{l}86 \\
(48.9)\end{array}$ & $\begin{array}{l}44 \\
(39.6)\end{array}$ \\
\hline $\begin{array}{l}\text { Do you think children receive adequate/ necessary } \\
\text { medical care? }\end{array}$ & $32(30.8)$ & $\begin{array}{l}49 \\
(49.5)\end{array}$ & $\begin{array}{l}47 \\
(51.7)\end{array}$ & $\begin{array}{l}2 \\
(1.1)\end{array}$ & $\begin{array}{l}37 \\
(33.3)\end{array}$ \\
\hline Do you think all children get free primary education? & $44(42.3)$ & $\begin{array}{l}45 \\
(45.0)\end{array}$ & $\begin{array}{l}39 \\
(42.9)\end{array}$ & $\begin{array}{l}2 \\
(1.1)\end{array}$ & $\begin{array}{l}33 \\
(29.7)\end{array}$ \\
\hline $\begin{array}{l}\text { Do you think children from minority communities are } \\
\text { discriminated against in the enjoyment of their } \\
\text { culture and the practice of their religion and } \\
\text { language? }\end{array}$ & $28(26.9)$ & $\begin{array}{l}53 \\
(54.6)\end{array}$ & $\begin{array}{l}44 \\
(48.4)\end{array}$ & $\begin{array}{l}17 \\
(9.7)\end{array}$ & $\begin{array}{l}50 \\
(45.1)\end{array}$ \\
\hline $\begin{array}{l}\text { Do you think children get sufficient/adequate leisure } \\
\text { time or time for play and recreation? }\end{array}$ & $26(25.0)$ & $\begin{array}{l}59 \\
(59.6)\end{array}$ & $\begin{array}{l}35 \\
(38.5)\end{array}$ & $\begin{array}{l}7 \\
(4.0)\end{array}$ & $\begin{array}{l}45 \\
(40.5)\end{array}$ \\
\hline $\begin{array}{l}\text { Do you think children are protected from work that } \\
\text { threatens their health, education and development? }\end{array}$ & $26(25.0)$ & $\begin{array}{l}41 \\
(41.4)\end{array}$ & $\begin{array}{l}43 \\
(47.3)\end{array}$ & $\begin{array}{l}7 \\
(4.0)\end{array}$ & $\begin{array}{l}25 \\
(22.5)\end{array}$ \\
\hline
\end{tabular}

\subsection{Multiple Regression Analysis for Knowledge and Perception about Child Rights}

A total score for knowledge and perception was calculated by summing up items scores (yes $=1$, no $=0$, respectively). Higher scores indicate better knowledge or more positive perception. The knowledge score ranged from 0 to 14 , with a mean of $8.50(\mathrm{SD}=3.01)$. The mean (SD) of the perception score was 2.34 (1.94) and the range was 0-7. These scores for each sub-group are presented in Table 5. Bivariate test (t-test or one-way ANOVA) showed that the knowledge score was significantly different across cities, participant categories, education levels and income levels $(\mathrm{p}<0.05)$. The perception score was significantly different between cities, participant categories, number of children and income levels.

Multiple regression analysis showed $33 \%$ of the total variance in knowledge score was explained by the model with all demographic variables $\left(\mathrm{F}_{(18,547)}=16.26, \mathrm{p}<0.001\right.$, adjusted $\left.\mathrm{R}^{2}=0.327\right)$. City of residence, participant category and income level were found to be strong determinants of knowledge score in the multiple model (Table 5). Participants from Puducherry had the highest knowledge score while those from Delhi had the lowest score. Compared to parents, teachers and community members reported significantly better awareness of child rights. High family income was associated with higher score in knowledge.

For perception score, the model was also statistically significant $\left(\mathrm{F}_{(18,548)}=10.91, \mathrm{p}<0.001\right.$, adjusted $\left.\mathrm{R}^{2}=0.240\right)$. Similar to knowledge score, city of residence and participant category had a significant effect on perception score. Participants from Delhi had the lowest score while those from Chennai had the highest, which was different from the order in knowledge score. Teachers had significantly higher scores than did patents. There was no significant relationship between other variables and perception score. 
Table 5. Results of multiple regression analysis for knowledge and perception scores $(\mathrm{N}=584)$

\begin{tabular}{|c|c|c|c|c|}
\hline \multirow[t]{2}{*}{ Variables } & \multicolumn{2}{|l|}{ Knowledge } & \multicolumn{2}{|l|}{ Perception } \\
\hline & $\mathrm{M}(\mathrm{SD})$ & Regression coefficient & $\mathrm{M}(\mathrm{SD})$ & Regression coefficient \\
\hline \multicolumn{5}{|l|}{ City } \\
\hline Puducherry & $10.54(1.55)$ & Ref & $2.26(1.45)$ & Ref \\
\hline Kerala & $9.52(3.14)$ & $-1.06(-1.85 \text { to }-0.26)^{* *}$ & $3.33(2.23)$ & $1.10(0.57 \text { to } 1.64)^{* * *}$ \\
\hline Chennai & $8.07(2.87)$ & $-2.98(-3.79 \text { to }-2.17)^{* * *}$ & $3.40(2.06)$ & $1.32(0.76 \text { to } 1.87)^{* * *}$ \\
\hline Delhi & $6.77(2.35)$ & $-4.97(-5.73 \text { to }-4.21)^{* * *}$ & $1.06(0.92)$ & $-1.20(-1.71 \text { to }-0.68)^{* * *}$ \\
\hline Kolkata & $8.85(3.39)$ & $-2.64(-3.49 \text { to }-1.79)^{* * *}$ & $2.73(2.01)$ & $0.68(0.10 \text { to } 1.25)^{*}$ \\
\hline \multicolumn{5}{|l|}{ Category } \\
\hline Parents & $8.02(3.28)$ & Ref & $2.54(2.12)$ & Ref \\
\hline Teachers & $9.58(2.43)$ & $1.91(1.37 \text { to } 2.45)^{* * *}$ & $2.39(1.78)$ & $0.42(0.05 \text { to } 0.79)^{*}$ \\
\hline $\mathrm{CMs}$ & $7.71(2.89)$ & $0.99(0.14 \text { to } 1.84)^{*}$ & $1.93(1.78)$ & $0.34(-0.24$ to 0.92$)$ \\
\hline \multicolumn{5}{|l|}{ Gender } \\
\hline Males & $8.40(3.09)$ & Ref & $2.28(2.04)$ & Ref \\
\hline Females & $8.57(2.97)$ & $-0.09(-0.53$ to 0.35$)$ & $2.38(1.87)$ & $-0.09(-0.39$ to 0.21$)$ \\
\hline \multicolumn{5}{|l|}{ Age } \\
\hline$<30$ years & $8.29(2.98)$ & Ref & $2.17(1.86)$ & Ref \\
\hline $31-35$ & $8.96(2.83)$ & $0.10(-0.57$ to 0.77$)$ & $2.33(1.86)$ & $0.10(-0.35$ to 0.56$)$ \\
\hline $36-40$ & $8.39(2.90)$ & $0.35(-0.42$ to 1.13$)$ & $2.48(2.01)$ & $0.43(-0.11$ to 0.96$)$ \\
\hline $41-45$ & $8.05(3.15)$ & $0.32(-0.50$ to 1.14$)$ & $2.08(1.87)$ & $-0.03(-0.59$ to 0.53$)$ \\
\hline $46-50$ & $9.10(3.18)$ & $0.69(-0.28$ to 1.67$)$ & $2.69(2.07)$ & $-0.11(-0.78$ to 0.56$)$ \\
\hline$\geq 51$ years & $8.34(3.29)$ & $-0.16(-1.15$ to 0.83$)$ & $2.61(2.14)$ & $-0.66(-1.33$ to 0.00$)$ \\
\hline \multicolumn{5}{|l|}{ Education level } \\
\hline Below graduate & $9.42(3.20)$ & Ref & $2.71(1.68)$ & Ref \\
\hline Graduate & $8.09(3.11)$ & $-0.15(-0.93$ to 0.64$)$ & $2.37(1.90)$ & $-0.04(-0.58$ to 0.49$)$ \\
\hline Postgraduate & $8.54(2.90)$ & $0.26(-0.53$ to 1.06$)$ & $2.26(1.99)$ & $-0.10(-0.64$ to 0.45$)$ \\
\hline \multicolumn{5}{|l|}{ Number of children } \\
\hline None & $8.43(2.82)$ & Ref & $1.92(1.64)$ & Ref \\
\hline One & $8.25(3.17)$ & $0.48(-0.35$ to 1.31$)$ & $2.16(2.00)$ & $0.38(-0.18$ to 0.94$)$ \\
\hline Two or more & $8.75(3.02)$ & $0.45(-0.38$ to 1.28$)$ & $2.79(2.01)$ & $0.47(-0.09$ to 1.03$)$ \\
\hline \multicolumn{5}{|l|}{ Income level } \\
\hline Low $(<$ Rs.20K $)$ & $8.92(3.18)$ & Ref & $2.77(2.01)$ & Ref \\
\hline Middle(20 - 50K) & $8.13(2.89)$ & $0.22(-0.39$ to 0.82$)$ & $2.44(1.89)$ & $0.14(-0.27$ to 0.55$)$ \\
\hline $\operatorname{High}(50 \mathrm{~K}+)$ & $8.66(3.01)$ & $1.52(0.81 \text { to } 2.22)^{* * * *}$ & $1.98(1.87)$ & $-0.12(-0.60$ to 0.36$)$ \\
\hline
\end{tabular}

Note. $\mathrm{CMs}=$ community members; Rs=Indian Rupees; $\mathrm{K}=$ thousand; ref=reference group

Statistical test for multiple regression coefficients: ${ }^{*} \mathrm{p}<0.05,{ }^{* *} \mathrm{p}<0.01,{ }^{* * *} \mathrm{p}<0.001$

\section{Discussion}

The present study explored the attitude of community members viz., parents', teachers' and others towards children's rights, knowledge of children's rights in Indian and international law, and perceptions of children's rights in lived experience. 


\subsection{Attitudes towards Child Rights}

Although the ddemographic and socio-economic background of the study population of five cities varied, participants generally expressed positive attitudes towards child rights, with $94 \%$ agreeing with at least six selected types of child rights out of seven as explored in the present study, which is a very encouraging sign. Unanimous positive attitudes of the participants across five cities towards child-rights include right to education, health, protection from inappropriate and damaging work, and to leisure, play and participation in cultural and artistic activities. There was also strong support for rights to freedom of expression of views. However, regarding a child's right to meet others, majority of the participants from Puducherry did not agree while participants from other cities were liberal about the same. Perhaps negative experiences of the participants from Puducherry about consequences of meeting others discouraged them to view about this right in a positive light. They might have thought that granting right to meet others has a possibility of involvement in socially undesirable activities and in turn they might deviate in negative direction. The extent of negative attitudes towards freedom to meet others may reflect a tendency towards social separation based on cultural standards regarding class, gender and religion. Findings of the present study in regard to general attitudes towards child rights corroborate with the findings of another Indian study carried out among parents and teachers of Agartala, Tripura (Deb \& Mathews, 2012). In case of earlier study carried out in Agartala (Tripura), most of the participants were not in favor of child right concerning expression of views, which was found to be favorable in the present multi-centric study across the five cities.

\subsection{Knowledge about Child Rights}

About $70 \%$ of the participants had knowledge about provisions in the Indian Constitution protecting child rights except participants from Delhi which is surprising. It was expected that the people from Delhi will have better knowledge. However, the issue requires further verification through a systematic study with large sample. So far as knowledge about the UN Convention on the Rights of the Child, about half of the participants across different cities were aware about it, except Chennai participants. Overall, knowledge of the participants of this multi-centric study about the same legislations or legal provisions was much better than the earlier study carried out covering parents and teachers of Agartala, Tripura (Deb \& Mathews, 2012).From the above mentioned evidence, it may be easily inferred that the level of knowledge of people with low educational background in the rural and urban set ups is significantly different and thus its influence also varies. This finding speaks for need of awareness of international legislations along with Indian laws. The awareness of child right related Indian laws and regulations varied among participants from one city to another city. Overall, the Rights of Children to Free and Compulsory Education Act 2009 had the highest awareness $(91.3 \%, \mathrm{n}=533)$, followed by the Child Labour (Prohibition and Regulation) Act, $1986(89.7 \%, \mathrm{n}=523)$ and the Prohibition of Child Marriage Act, 2006 (89.6\%, $\mathrm{n}=523$ ). Knowledge about these three legislations was comparatively better since there was a lot of discussion in the electronic media and number of articles in the print media about the same legislations.

\subsection{Perceptions of the Lived Experience of Children's Rights}

Participants across the cities gave a unanimous response about poor lived experiences of child rights in reality i.e., a large number of children do not enjoy freedom of expression of views, meeting others, medical care, free education, freedom from engagement in damaging work and so on. In this regard, significant difference has been observed in the perception of the participants across the cities. Surprisingly, the situation is worse in Delhi with regard to child rights concerning medical care, free education, non-discrimination, leisure time and protection from hazardous work.

The scenario of education is different in different regions. Taking into consideration the enrolment in the government schools, while Delhi $(10,49,443)$ and West Bengal $(91,20,325)$ have the highest enrolment numbers among the regions covered, they are also the regions whose percentage of out of school girl children (approximately 7\%) and percentage of rural and urban children out of school (approximately 5\%) is higher than the national average of $5.2 \%$ and $4.5 \%$ respectively. Puducherry has one of the lowest enrolment numbers among all the regions of India. Kerala, on the other hand, is one of the states having highest percentage of children attending private schools (59.4\%) and lowest drop- out rates (Survey Report of Social and Rural Research Institute under the MHRD, GOI, 2009).

The concept of leisure time in the lives of majority of the Indian children in day to day life is more of a theoretical concept now-a-days. In reality, majority of the children are deprived from leisure time because of strict routine life from early childhood, which are often the result of intense academic pressure from families, schools and private tutors to perform at high academic levels (Deb and Mathews 2012). Evidence indicates that high academic competitive environment affects children in the middle class badly, who aspire for higher social 
mobility (Deb et al. 2010) and finally academic pressure leads students to run away from families and/or development of suicidal ideation.

Available national data from the National Crime Records Bureau, Ministry of Home Affairs, Government of India (2009) indicate over 2000 people suicide with the listed cause of 'failure in examination', and of these, 291 were aged under 15 (National Crime Records Bureau 2010, p. 180). Compulsion for studying for a very longer time in a day under strict schedule mostly designed by the parents affects the freedom of children to enjoy leisure time, play and participation in activities. In most of the urban cities in India, there is a lack of adequate spaces, parks and playgrounds in urban areas, and parental reluctance to allow children to mix with other children also tends to deprive children of these rights (Deb \& Mathews, 2012).

In view of magnitude of the Indian population and its socio-economic characteristics, there is an urgent need for the Government of India to give more emphasis to promote some of the basic fundamental rights of the children for improving their living conditions. The most fundamental needs of any human being include the rights to health, the right to nutrition, the right to health care, the right to safety and to free primary school education. Other rights are connected with these, including freedom from inappropriate and damaging work, and freedom from childhood marriage. Therefore, special social policy for Indian children is needed for ensuring their basic fundamental rights.

Evidence clearly indicates that some of the rights enacted in Indian legislation, such as the prohibitions on child marriage, and on forced labour, are widely ignored. The new right to education is also yet to be implemented with sufficient breadth (Deb \& Mathews, 2012). India was assessed as having a 'low to zero' degree of implementation of child protection measures to establish a basic level of child protection as indicted by a study (Svevo-Cianci et al., 2010). In the context of child maltreatment, this study further reported that those nation's systems which were more successful were characterised by two social programs: a child protection infrastructure comprising legislation and services, and a minimum of one information-based intervention support program. This apart, professional training and public awareness-raising were other important essential steps in improving child protection from abuse and neglect in addition to raising awareness and developing better attitudes towards children's rights. The newly constituted right to free primary education and protection of children from sexual offences must be accompanied by measures to ensure that it is implemented. Child marriage, forced labour, and inappropriate labour practices must also be minimised through income generating programs for the families living below the poverty line. Implementation of federal law is the binding and obligation of the every state government. Therefore, sensitization of the respective ministers of each state about child rights issue is very essential and for that federal government should organise a special sensitization program for them and ensure that all the minister of all the states and respective higher administrative and program implementing personnel attend the sensitization program. Then only one can expect some proactive measures at the state level for protection of child rights. Proper governance and accountability, including periodic monitoring and evaluation of the laws' implementation, and dissemination of results, is essential (Deb \& Mathews 2012). It is relevant to mention here that there have been some recent significant proposals to implement children's fundamental rights in India, including plans for renewed systemic commitments to child health, especially in the first two years of life (Paul et al. 2011), and a proposal to develop an Integrated National Health System (Reddy et al. 2011). As well, there are proposed guidelines for the recognition and management of child abuse in pediatric settings (Aggarwal et al. 2010). The issue of sustainability of all child related welfare and development programs should be ensured in addition to campaigning child rights through electronic media.

\section{Conclusion and Recommendations}

Although attitudes of the participants about seven stated child rights was very positive across the cities, about half of the participants have not heard about the UN Convention on the Rights of the Child. However, knowledge about provisions in the Indian Constitution protecting child rights, and other specific child rights related legislations was good. City of residence, participant category and income level were found to be strong determinants of knowledge regarding child rights. Participants from Puducherry had the highest knowledge compared to participants from Delhi. Compared to parents, teachers and community members reported significantly better awareness of child rights. High family income was associated with higher score in knowledge.

Similar to knowledge score, city of residence and participant category had a significant effect on perception about child rights. Participants from Delhi had the lowest score while those from Chennai had the highest score regarding perception of lived experiences of child rights in reality. In other words, it might be stated that children in Chennai enjoy better rights compared to children from Delhi as perceived by the participants. 
Finally, the findings of this study indicate a need to improve attitudes towards children's rights generally, with a particular focus on selected rights like right to meet others. In association with this, there is a need to raise awareness of domestic and international laws which seek to promote these fundamental rights among both rural and urban community members. Awareness-creation using electronic media needs to occur at a societal level, with additional emphasis within the most influential groups: parents, teachers and other community members. While creating awareness through electronic media, emphasis should be given on sign and symptoms of various forms of abuse and neglect, profile of potential perpetrators, legal measures available for rendering justice to the victim, detailed information about penalties for violation of child rights, phone number and addresses in different locations for reporting of the incidents and addresses of safe shelters and grass root level organizations for rescue of children in difficult situations. Given that there are some fundamental rights which are frequently breached with great cost caused to children and society - such as the rights to health and education, and the prohibitions of child marriage and inappropriate child labour - it would be most profitable to also direct resources towards improving attitudes towards children in those industries.

\section{Limitations}

This study was confined to urban community members of five cities only, who were highly educated, employed and coming from middle and above socio-economic background. Secondly, the findings of the study are based on self-report. Third, although ethical issues were strictly followed for data collection and the study subjects were ensured about confidentiality of information, there is a possibility that some of the study subjects might give response to probe their better knowledge about child rights. Therefore, caution should be taken to generalise the findings. For having better picture about the issue, it would be beneficial to conduct a study with large sample drawing sample from both urban and rural areas. It would also be beneficial to explore the attitudes, knowledge and perceptions of people of different classes of India. Finally, this empirical study did not include two latest legislations conferred the right to free primary school education (The Right of Children to Free and Compulsory Education Act or Right to Education Act (RTE), 2009) and The Protection of Children from Sexual Offences Act, 2012 (POCSO Act 2012). Therefore, it would be interesting to carry out another study to understand knowledge, attitude and perception of the community members about the above two legislations.

\section{Declaration of Conflict of Interests}

The author/s declared no potential conflicts of interest with respect to the authorship and/or publication of this article.

\section{References}

Aggarwal, K., Dalwai, S., Galagali, P., Mishra, D., Prasad, C., \& Thadhani, A. (2010). Recommendations on recognition and response to child abuse and neglect in the Indian setting. Indian Pediatrics, 47(6), 493-504. http://dx.doi.org/10.1007/s13312-010-0088-0

Ben-Arieh, A., Khoury-Kassabri, M., \& Haj-Yahia, M. M. (2006). Generational, ethnic, and national differences in attitudes toward the rights of children in Israel and Palestine. American journal of orthopsychiatry, 76(3), 381. http://dx.doi.org/10.1037/0002-9432.76.3.381

Bhattacharyya, A. K. (1979). Child abuse in India and nutritionally battered child. Child Abuse \& Neglect, 3(2), 607-614. http://dx.doi.org/10.1016/0145-2134(79)90087-5

Bunting, L., Webb, M. A., \& Healy, J. (2010). In two minds? - parental attitudes toward physical punishment in the UK. Children \& Society, 24(5), 359-370.

Casas, F., Saporiti, A., Gonzalez, M., Figuer, C., Rostan, D., Sadurni, M., ... Rago, M. (2006). Children's rights from the point of view of children, their parents and their teachers: A comparative study between Catalonia Spain and I1 Molise Italy. International Journal of Children's Rights, 14, 1-75. http://dx.doi.org/10.1163/157181806776614336

Chen, J., Dunne, M. P., \& Han, P. (2007). Prevention of child sexual abuse in China: Knowledge, attitudes, and communication practices of parents of elementary school children. Child Abuse \& Neglect, 31(7), 747-755. http://dx.doi.org/10.1016/j.chiabu.2006.12.013

Day, D. M., Peterson-Badali, M., \& Ruck, M. D. (2006). The relationship between maternal attitudes and young people's attitudes toward children's rights. Journal of Adolescence, 29(2), 193-207. http://dx.doi.org/10.1016/j.adolescence.2005.05.002

de Silva, W. (1981). Some cultural and economic factors leading to neglect, abuse and violence in respect of children within the family in Sri Lanka. Child Abuse \& Neglect, 5(4), 391-405. 
http://dx.doi.org/10.1016/0145-2134(81)90049-1

Deb, S., \& Modak, S. (2010). Prevalence of violence against children in families in Tripura and its relationship with socio-economic factors. Journal of Injury and Violence Research, 2(1), 5. http://dx.doi.org/10.5249/jivr.v2i1.31

Deb, S., Chatterjee, P., \& Walsh, K. (2010). Anxiety among high school students in India: comparisons across gender, school type, social strata and perceptions of quality time with parents. Australian Journal of Educational \& Developmental Psychology, 10, 18-31.

Deb, S., Mukherjee, A., \& Mathews, B. (2011). Aggression in sexually abused trafficked girls and efficacy of intervention. Journal of Interpersonal Violence, 26(4), 745-768. http://dx.doi.org/10.1177/0886260510365875

Finkelhor, D., Turner, H., Ormrod, R., \& Hamby, S. L. (2010). Trends in childhood violence and abuse exposure: evidence from 2 national surveys. Archives of Pediatrics \& Adolescent Medicine, 164(3), 238-242. http://dx.doi.org/10.1001/archpediatrics.2009.283

Ghosh, B. (2009). Trafficking in women and children in India: Nature, dimensions and strategies for prevention. The International Journal of Human Rights, 13(5), 716-738. http://dx.doi.org/10.1080/13642980802533109

Gilbert, R., Widom, C. S., Browne, K., Fergusson, D., Webb, E., \& Janson, S. (2009). Burden and consequences of child maltreatment in high-income countries. The lancet, 373(9657), 68-81. http://dx.doi.org/10.1016/S0140-6736(08)61706-7

Hannum, E., Kong, P., \& Zhang, Y. (2009). Family sources of educational gender inequality in rural China: A critical assessment. International Journal of Educational Development, 29(5), 474-486. http://dx.doi.org/10.1016/j.jjedudev.2009.04.007

Kempe, C. H., Silverman, F. N., Steele, B. F., Droegemueller, W., \& Silver, H. K. (1984). The battered-child syndrome. JAMA, 251(24), 3288-3294. http://dx.doi.org/10.1001/jama.1984.03340480070033

May-Chahal, C., \& Cawson, P. (2005). Measuring child maltreatment in the United Kingdom: A study of the prevalence of child abuse and neglect. Child Abuse \& Neglect, 29(9), 969-984. http://dx.doi.org/10.1016/j.chiabu.2004.05.009

Mehta, M. N., Liokeshwar, M. R., Bhatt, S. S., Athavale, V. B., \& Kulkarni, B. S. (1979). 'Rape'in children. Child Abuse \& Neglect, 3(3), 671-677. http://dx.doi.org/10.1016/0145-2134(79)90096-6

Nair, P. M., \& Sen, S. (2005). Trafficking in women and children in India. Orient Blackswan.

National Crime Records Bureau. (2010). Accidental Deaths and Suicides in India: 2009. Delhi: Ministry of Home Afffairs, Government of India, 180. Retrieved September 28, 2011, from http://ncrb.nic.in/CD-ADSI2009/ADSI2009.htm

Paul, V. K., Sachdev, H. S., Mavalankar, D., Ramachandran, P., Sankar, M. J., Bhandari, N., \& Kirkwood, B. (2011). Reproductive health, and child health and nutrition in India: Meeting the challenge. The Lancet, 377(9762), 332-349. http://dx.doi.org/10.1016/S0140-6736(10)61492-4

Reddy, K. S., Patel, V., Jha, P., Paul, V. K., Kumar, A. K., \& Dandona, L. (2011). Towards achievement of universal health care in India by 2020: a call to action. The Lancet, 377(9767), 760-768. http://dx.doi.org/10.1016/S0140-6736(10)61960-5

Ronan, K. R., Canoy, D. F., \& Burke, K. J. (2009). Child maltreatment: Prevalence, risk, solutions, obstacles. Australian Psychologist, 44(3), 195-213. http://dx.doi.org/10.1080/00050060903148560

Runyan, D. K., Shankar, V., Hassan, F., Hunter, W. M., Jain, D., Paula, C. S., ... Bordin, I. A. (2010). International variations in harsh child discipline. Pediatrics, peds-2008. http://dx.doi.org/10.1542/peds.2008-2374

Segal, U. A. (1992). Child abuse in India: An empirical report on perceptions. Child Abuse \& Neglect, 16(6), 887-908. http://dx.doi.org/10.1016/0145-2134(92)90090-E

Segal, U. A. (1995). Child abuse by the middle class? A study of professionals in India. Child Abuse \& Neglect, 19(2), 217-231. http://dx.doi.org/10.1016/0145-2134(94)00118-E

Social and Rural Research Institute. (2009). All India survey of out-of-school children of age 5 and 6-13, years of Age Group, Ministry of Human Resource Development, GOI.

Svevo-Cianci, K. A., Hart, S. N., \& Rubinson, C. (2010). Protecting children from violence and maltreatment: A 
qualitative comparative analysis assessing the implementation of UN CRC Article 19. Child Abuse \& Neglect, 34(1), 45-56. http://dx.doi.org/10.1016/j.chiabu.2009.09.010

The Child Abuse Prevention and Treatment Act, CAPTA (US).(1974).

The Child Labour (Prohibition and Regulation) Act.(1986).

The Child Marriage Restraint Act.(1929).

The Commissions for the Protection of the Child Rights Act.(2005).

The Immoral Traffic (Prevention) Act.(1956).

The Indian Constitution, Nov. 26, 1949 (enforced on Jan.26, 1950).

The Indian Penal Code, 1860.

The Infant Milk Substitutes, Feeding Bottles and Infant Foods (Regulation of Production, Supply and Distribution) Act, 1992 (amended in 2003).

The Juvenile Justice (Care and Protection of Children) Act, 2000 (amended in 2006, India).

The National Charter for Children. (2003).

The National Crime Records Bureau 2010, Ministry of Home Affairs, Government of India

The Persons with Disabilities (Equal Opportunities, Protection of Rights, and Full Participation) Act, 1995.

The Pre-natal Diagnostic Techniques (Regulation and Prevention of Misuse) Act, 1994

The Prohibition of Child Marriage Act, 2006.

The Protection of Children from Sexual Offences Act, 2012.

The Rights of Children to Free and Compulsory Education Act, 2009.

The United Nations Convention on the Rights of the Child (UNCRC) 1989.

Verma, R. K., Pulerwitz, J., Mahendra, V., Khandekar, S., Barker, G., Fulpagare, P., \& Singh, S. K. (2006). Challenging and changing gender attitudes among young men in Mumbai, India. Reproductive Health Matters, 14(28), 135-143. http://dx.doi.org/10.1016/S0968-8080(06)28261-2

Yeatman, G. W., Shaw, C., Barlow, M. J., \& Bartlett, G. (1976). Pseudobattering in Vietnamese children. Pediatrics, 58(4), 616-618.

\section{Copyrights}

Copyright for this articleis retained by the author(s), with first publication rights granted to the journal.

This is an open-access article distributed under the terms and conditions of the Creative Commons Attribution license (http://creativecommons.org/licenses/by/4.0/). 